\title{
Thai Sikhs: Model of Conservation and Succession of Identity for Peaceful Existence in Thai Society
}

\author{
Nakrob Narksuwan ${ }^{1}$, Wisanee Siltragool ${ }^{1} \&$ Anchalee Jantapo $^{1}$ \\ ${ }^{1}$ The Faculty of Cultural Science, Mahasarakham University, Khamriang Sub-District, Kantarawichai District, \\ Maha Sarakham 44150, Thailand
}

Correspondence: Nakrob Narksuwan, Mahasarakham University, Khamriang Sub-District, Kantarawichai District, Maha Sarakham 44150, Thailand. E-mail: nakrob@dtc.ac.th

\author{
Received: August 6, 2013 Accepted: October 11, 2013 Online Published: December 31, 2013 \\ doi:10.5539/ass.v10n1p243 URL: http://dx.doi.org/10.5539/ass.v10n1p243
}

\begin{abstract}
The objectives of this research are to examine the background and important identity of the Thai Sikhs in the Bangkok area, to investigate the current situations and problems of conservation and succession of the Thai Sikh identity in the Bangkok area and to study the model of conservation and succession of Thai Sikh identities so that Thai Sikhs may live peacefully in Thai society. Interviews, observations, group discussion, and workshops among the Thai Sikhs were applied as research methods. The areas of study were Pahurat, Pra Nakorn District, Gurdwara Sri Guru Singh Sabha, Pra Nakorn District, and Im-Amporn Village, Bangkok Yai District. The results indicated that the Thai Sikhs first came to Thailand and worked as patrolmen during the reign of King Rama IV. In the reign of King Rama V, they began to settle down at Baan Mor, Pahurat, Pra Nakorn District, Bangkok. After adjusting to the circumstances, they started selling textiles to earn their livings. When this area became too congested, the Thai Sikhs moved away to other areas around Bangkok. The significant aspects of Thai Sikh identity are the five K symbols, doctrines and ceremonies, Gurdwara Sri Guru Singh Sabha, Sri Guru Singh Sabha Association and Punjabi language. At present, the identity of the Thai Sikhs is still strong and obvious in Thai society. The problems include the fact that their identity may be gradually replaced by modern cultures from other societies and the neglect of the Thai Sikhs. The suggested solutions include giving knowledge and creating activities to inculcate the awareness of identity conservation in the Thai Sikhs, which requires the collaboration of Thai Sikh people and relevant organizations. The model of conservation and succession of identity for peaceful living in Thai society should begin with study of the Thai Sikh context, important aspects of identity and their problems, and objectives of identity conservation and succession. The principles of conservation and succession are inculcating the value awareness of significant aspects of identity, providing knowledge about significant aspects of identity and holding practical activities to boost the conservation of significant aspects of identity, which are aimed at creating a peaceful life for Sikhs in Thai society.
\end{abstract}

Keywords: Thai Sikhs, identity, conservation, succession

\section{Introduction}

Community identities represent the behaviors and various activities established, respected and accepted mutually within the community. This includes eating habits, costumes, work, relaxation, and other kinds of lifestyles. Certain identities have been kept or adjusted slightly according to the environment in order for people to live peacefully within a foreign society and culture. A good example is the conservation and adjustment of the Thai Sikh identity in Thailand. They have adjusted themselves to the major culture in which they have lived. There have been some relevant studies including the adjustment to cultural society in Thailand by Polsak Jirakraisiri (cited in Chantaronanon, 2008, p. 2), which indicated the fact about the adjustment to the capital city that 'Bangkok is an area of great culture, which is Thai culture. This is the country's main culture. Therefore, the refugees' adjustment to the culture here was not complicated. They only faced the main culture.'

The abundant resources of Thailand are major factors fostering the immigration of various ethnic groups, such as the Chinese, Mon, Muslim, and Indian, for the purpose of merchandising or settling down. Another factor is the fact that Thai people are liberal. They never offend foreigners, nor restrict different religious beliefs. Most importantly, the Thai King is kind to the refugees who emigrate from hardship in their own countries. Many 
ethnic groups have flown into Thailand, especially Indians, who settled down in Thailand hundreds of years ago and established their original cultures in many ways. Apart from settling down in Thailand, Indians are also well-known for their trading activities. They smoothly adjusted themselves to the climate of Thai society, and kept significant aspects of their identity until today.

The Sikhs from the Punjab region, which is located in the North of India, came to Thailand during the reign of King Rama V. They took years to establish the Pahurat Community, Baan Mor, Samphanwong. In 1912, the Gurdwara, a Sikh religious place, was built. When their community grew stronger, the Gurdwara was moved to a bigger site on the corner of Pahurat road and Chakpetch Road. After restoration was finished, the Holy Scripture Guru Granth Sahib was brought to the Gurdwara so that the Sikhs could pay respect and practice the religious rites every day.

According to the encyclopedia, it is recorded that there are 70,000 Thai Sikhs and 18 Sikh temples in Thailand (Wikipedia, 2012). Most of them live in the Bangkok area, since Bangkok is the center of politics, economy, society and culture. Most of the Thai Sikhs, therefore, chose to live and work in Bangkok. They have gathered together and established a unique community. The older generations of Thai Sikhs loved and valued their identity highly. However, they were able to adjust themselves to the different culture in Thailand. Even though there was a diversity of cultures, religions, beliefs, and practices, the Thai Sikhs were still able to keep their identity. Nevertheless, the young Thai Sikhs have gradually absorbed the external cultures. They accept, imitate and keep them as a part of their lives. This might cause them to forget the original identity inherited from their ancestors.

For these reasons, the researchers were interested in studying the ways of conservation and succession of Sikh identity for the peaceful life in Thailand. The research includes studying the background and identity of the Thai Sikhs and the current situation and problems about the major aspects of their identity, in order to explore the factors affecting the conservation and succession of their identity for a peaceful life in Thailand. The research also strove to find an appropriate model of conservation and succession of the identities of other ethnic groups and communities.

\section{Research Objectives}

The objectives of this research, Thai Sikhs: Model of Conservation and Succession of Identity for Peaceful Existence in Thai Society were threefold: a) to examine the background and important aspects of Thai Sikh identity in the Bangkok area; b) to investigate the current situations and problems with conservation and succession of Thai Sikh identity in the Bangkok area; c) to study the model of conservation and succession of Thai Sikh identity so that Thai Sikhs may live peacefully in Thai society.

\section{Research Methodology}

A qualitative research technique was applied to this study Sikhs: Model of Conservation and Succession of Identity for Peaceful Existence in Thai Society. The researchers set the phases, methods of gathering data, and the numbers of population and sample groups. The details of the method could be divided into two parts as follows:

\subsection{Scope of the Study}

The scope of this study included the examination of the background and important identities of the Thai Sikhs in the Bangkok area, investigation of the current situations and problems with conservation and succession of Thai Sikh identity in the Bangkok area and study of the model of conservation and succession of Thai Sikh identity so that Thai Sikhs may live peacefully in Thai society.

A qualitative method was used for the study of identity and knowledge of social and cultural context was required. The researchers needed to collect information and take part in the activities themselves to obtain the most accurate data.

The selected study areas were residential districts and religious places of Thai Sikhs in Bangkok, which included: a) Im-Amporn Village, Soi Charan Sanitwong 13, Bangkok Yai District, Bangkok; b) Gurdwara Sri Guru Singh Sabha, Pra Nakorn District; c) Pahurat Intersection area, Pra Nakorn District, Bangkok

\subsection{Population and Sample Group}

The population in this study was comprised of normal Thai Sikhs, including scholars, businesspeople, merchants, and students in Gurdwara Sri Guru Singh Sabha, Pahurat Intersection area, and Im-Amporn Village, Bangkok Yai District, Bangkok. The sample represents the population of the research. The number of samples who would be interviewed was indicated. The researcher chose to apply two methods of sampling, which were purposive 
sampling and random sampling. The details are as follows:

1) Key informants included the Thai Sikh scholars living in the study area, the committee of the Gurdwara Sri Guru Singh Sabha and Sri Guru Singh Sabha Association.

2) Casual informants included the Thai Sikhs living in the study area.

3) General informants included the Thai Sikhs who came to practice at the Gurdwara Sri Guru Singh Sabha and Sri Guru Singh Sabha Association and general people who contacted or had relationship with the Thai Sikhs.

The research method was arranged as follows:

\subsection{Research Tools}

\subsubsection{Field Notes}

Field notes were used to record the information obtained during the observations, interviews and group discussions.

\subsubsection{Interview}

In this study the oral history interview, non-structured interview and structured interview were the applied methods. The structured interview was used to gather personal information, including gender, status, education backgrounds, occupation, monthly salary, important aspects of identity, current situation, problems and solutions, identity conservation and succession from the respondents. In the meantime, the non-structured interview, comprised of a list of non-restricted questions, was used to ask for information from the key informants about the history, identity, current situations, problems and solutions, and the suggested models of conservation and succession of Thai Sikh identity so that Thai Sikhs may live peacefully in Thai society.

\subsubsection{Group Discussion}

The discussion was conducted by the researchers with a group of three to four key informants and general Thai Sikhs. The information obtained from the discussion was the important aspects of identity which deserved to be conserved and succeeded. There were also suggestions of the models of doing so.

\subsubsection{Observation}

This method was applied to examine various contexts related to the identities of the Thai Sikhs. This included participant observation in the ceremonies and religious activities, while non-participant observation was used to follow their daily routines and activities in the research area.

\subsection{Data Collection}

\subsubsection{Literature Review}

The historical documents about Thai Sikh society and culture were studied.

\subsubsection{Field Studies}

Most of the data supporting this research was obtained from field studies. The researcher gathered data by interviewing, discussing with and observing the sample population and making records.

\subsection{Data Processing and Analyzing}

The data collected from primary and secondary sources, including the information recorded during the field studies, was analyzed. Then a list of relevant questions was scoped and created to be used in the interview.

The data obtained from the field studies, group discussions and workshops was verified before being categorized according to the typologies or objectives of the study.

In analyzing the data, triangulation method was applied to check the reliability of information in three aspects, which were data, place and personal.

\subsection{Presentation of the Results}

The research results were presented using analytical description according to the obtained data.

\section{Research Results}

\subsection{The Background and Significant Aspects of Thai Sikh Identity in the Bangkok Area}

\subsubsection{The Background of the Thai Sikhs}

It was documented that the first group of Sikhs came to Thailand during the reign of King Rama IV. At that time, Prince Nares Worarit sent a letter to the King reporting the number of Indian patrolmen working for the Thai 
government. When King Rama V, the next monarch, visited Phuket, he wrote in his journal about the Sikh police who came to welcome him. Apart from the written records, it was also told that the Sikhs arrived in Thailand during the reign of King Rama V. Leaving from the Punjab region, they came to Thailand primarily for the purpose of merchandising. Their main trading center was behind the shop-houses around Pahurat Road, where they sold fabric and other goods imported from India. Some of them were peddlers travelling around to sell fabric both for cash and for credit. When the Sikh population had increased, the Gurdawara was established in 1913 at a rented house on Pahurat Road. In 1932, the Sikhs purchased a piece of land and built a new religious place, officially named Gurdwara Siri Guru Singh Sabha. They also established the Siri Guru Singh Sabha Association, which has represented the Sikhs in Thailand. For this reason, Pahurat and the adjacent areas have been the center of settlement and activities of the Thai Sikhs.

The Sikh community has expanded to other areas in Bangkok such as Sukhumvit (Soi Nana to Soi Thanglor) Baan Khaek Intersection, Tha Phra and Charan Sanitwong 13. They earned their living not only from selling fabric but also from opening up their businesses, being doctors, lawyers and teachers. Even though some Sikhs moved out from Pahurat, they still come here for it is the center of their religious ceremonies and trading.

\subsubsection{Significant Aspects of the Thai Sikh Identity}

The research found that the significant Sikhism-based identities that the Thai Sikhs respected include the five K symbols, doctrines and ceremonies, Gurdwara Siri Guru Singh Sabha, Siri Guru Singh Sabha Association, and Punjabi language.

The five K symbols are found in every single person who follows the Sikh faith. After participating in the Sikh baptism ceremony, the Thai Sikhs will be given the five K symbols, which they keep for their entire lives. For men, these are wearing long hair under the turban (Kesh), carrying a small comb (Kangha), wearing a steel bracelet on the right hand (Kara), wearing a necklace with a pendant of small sword (Kirpan) and wearing a pair of shorts (Kachera). The women do everything as the men do, except for the hair, which they keep neat under a piece of scarf.

The doctrines which the Thai Sikhs apply in their daily lives derive from the Guru Granth Sahib. The first teaching is knowing and controlling oneself, which includes controlling one's own behavior, controlling subordinate people and controlling one's work. The second teaching indicates attempt to follow the teachings, which is the philosophy of living. The third teaching is being socially-conscious and self-dedicated.

The ceremonies include the religious practices inherited from the ancestors in order to strengthen the relationship among the Thai Sikhs. They also express their faith in the religion by conducting the ceremonies, as each ceremony must be performed in the presence of the Guru Granth Sahib or with the psalm from the Guru Granth Sahib. The ceremonies can be divided as God praising, baptism, praying with music performance, turban tying, Guru ka Langar, Seva or community service, and ceremonies related to religious days. As for the secular ceremonies, they are praying ceremony, naming a child, marriage and funeral.

Gurdwara Siri Guru Singh Sabha was the residence of the last prophet, the Guru Granth Sahib. Therefore, this is the place where religious ceremonies take place as well as where the Thai Sikhs gather together. At present, Gurdwara Siri Guru Singh Sabha is a beautiful six-storey building located in Pahurat Intersection, Phra Nakorn District, Bangkok. Every day the Thai Sikhs come here to perform the religious ceremonies, pray, praise God, have a meal in the Guru ka Langar and discuss their lives. They also gather together to join the activities of the Gurdwara. This place opens to the public, so people can visit and pay respect to the Guru Granth Sahib or perform the ceremonies every day.

Siri Guru Singh Sabha Association was established by the Thai Sikhs in Thailand. It was registered with the National Council of Cultural Affairs in 1963. After that, the Thai government reorganized the religious bodies by declaring that all religious organizations had to be registered with the Department of Religious Affairs. Therefore, the Siri Guru Singh Sabha Association was re-registered and lawfully considered a religion in Thailand. The office is located in Gurdwara Siri Guru Singh Sabha, Bangkok. The committee of the Association must have faith in Sikhism, the ten gurus and the Guru Granth Sahib. Also, they must perform the ceremonies, strictly follow the Sikh way of life and be fluent in Punjabi language. The Association's job is to conserve the Sikh culture, introduce the teachings to the Thai Sikhs, and educate the young Thai Sikhs to be capable and virtuous. The Association also takes care of the activities held in the Gurdwara. They established a Thai Sikh school in Samutprakan, Guru Nanak foundation to help the Thai Sikh or general poor people. The most important act of the Association is fostering understanding between the Thai Sikhs and Thai people.

Punjabi language is the medium for teaching the doctrines in the Guru Granth Sahib, since this language was 
used to record the teachings of the ten gurus, prayers, and encomia. Some elderly Thai Sikhs also used Punjabi to communicate within their community. Although some young Thai Sikhs tend to use more Thai and English language in communication, some of them can speak Punjabi well. The role of Punjabi language has slightly changed due to the influence of English and Thai languages in the modern world.

\subsection{Current Situations and Problems with the Conservation and Succession of Thai Sikh Identity in the Bangkok} Area

\subsubsection{Current Situations}

The significant identity still obviously appears on the body and practice of the Thai Sikhs. Firstly, both men and women still wear five K symbols. Secondly, they still pray at the Gurdwara and the prayer room in their houses. They always perform the ceremonies, both religious and secular, in the presence of the Guru Granth Sahib at the Gurdwara. Thirdly, the Gurdwara is still the center of the Thai Sikhs. Fourthly, the Sri Guru Singh Association still acts as the representative of the Thai Sikhs in organizing social services. Lastly, they still use the Panjabi language to pray, perform ceremonies and communicate to each other.

\subsubsection{Problems with the Significant Aspects of Identity}

Their identities have been affected by: a) the changing social contexts that make them adjust to the working climate, society and education. For example, they may have to cut hair and get shaved; they sometimes face difficulty in traveling to the Gurdwara and they use less Panjabi at school and at work; b) the influence of new cultures, especially those absorbed by the young Thai Sikhs, such as hair cutting, hair coloring and ear piercing; c) some Thai Sikhs neglect the important aspects of identity as they have to work outside their home and do not have time to educate their kids.

\subsubsection{Methods of Conservation and Succession of Significant Aspects of Identity}

These include: a) inculcating the awareness of the significant identity value such as Punjabi language, which is the basis of teachings; b) giving knowledge of significant identities and practical activities to boost the significant identity conservation; c) organizing activities related to the identity conservation such as media, exhibitions, and demonstration which require collaboration between the Thai Sikhs.

\subsection{The Model of Conservation and Succession of Thai Sikh Identity So That Thai Sikhs May Live Peacefully in Thai Society}

According to the proposal of various methods analyzed by using information obtained from the field study, it was found that the Thai Sikhs were able to keep their significant identities such as the five $\mathrm{K}$ symbols, teachings and ceremonies, Gurdwara Sri Guru Sikh Sabha, Sri Guru Singh Sabha Association, and Punjabi language. These identities are based on Sikhism. The Thai Sikhs consider them as the representative of the Sikhs themselves. Therefore, they find it worth conserving and succeeding. The problems of conservation and succession, however, were found in many aspects. These include: a) the changing social contexts that make them adjust to the working climate, society and education; b) the influence of new cultures, especially those absorbed by the young Thai Sikhs, such as hair cutting, hair coloring and ear piercing; c) neglect of important aspects of identity; d) shortage of people responsible for taking care of identity. The objective of conservation and succession is to build the awareness of importance, value and pride of the identity among the young Thai Sikhs. They should be encouraged to collaborate in the conservation and succession with the relevant organizations. There should also be activities to promote and introduce these identities to the others. The principles of conservation and succession are to inculcate the value awareness of the significant aspects of identity, support the study and collection of information about the identity, and organize activities related to identity conservation such as media, exhibitions, and demonstrations, which require collaboration between the Thai Sikh organizations to achieve the goals of peaceful living in Thai society. The other factors encouraging peaceful living include paying respect to the monarchy, having stable financial status, working lawfully, accepting laws or social norms and helping and servicing community.

\section{Discussion}

According to the study, all significant aspects of Thai Sikh identity are symbols of Sikhism which have been inherited from ancestors in the Punjab region. These include the five K symbols: Kesh (long and unshorn hair), Kangha (a comb), Kara (a steel braclet), Kachera (pair of shorts) and Kirpan (a sword) granted to each Thai Sikh in the baptism ceremony. Teachings and ceremonies are important for their practices, which include praying, performing music with praying, Guru ka Langar, and turban tying. The Gurdwara was built to be the center of religious activities. Punjabi language has been used to pray and communicate in the community. All these symbols have been long respected for more than 500 years. Even though the change in identity has been found in 
some regions where the Sikhs settled down, it was just a slight change in the way of practice. The aforementioned identities are considered representative of the Sikhs, which comply with the Symbolic Interaction theory of George Herbert Mead (2012). He indicated that Symbolic Interaction occurs when people interact to each other through various symbols, including singing, signaling, and languages. It is believed that the importance of social relationship depends on possessing and using the same symbols. Society is formed not only by physical gathering but also from mind gathering. The actions they perform express some symbols which are both explicit and implicit. Pride, acknowledgment, felling and logic are also expressed.

According to the study, the problems of conservation and succession of identities mainly occur from the change in social contexts that affect the Thai Sikh identity. For example, the government agencies or private companies force their employees to cut hair and put on a hat while working. However, Thai Sikhs must wear long hair and tie turbans. Conflict, therefore, occurs. Modern cultures also affect the original identity, especially among the young Thai Sikhs, who easily absorb these cultures through social networks and media. This factor is in compliance with the study by Ngamphit Satsanguan (2008, pp. 257-270) about the family institution of ethnic groups in Bangkok, Thailand: a case study of the Vietnamese. It was stated that the Vietnamese did not keep their original ceremonies and cultures because they accepted new innovations and technology from outside. Therefore, it can be inferred that social contexts, cultures and individuals are the main factors affecting the conservation and succession of identity.

As the conservation and succession of identity is beyond individual ability, Thai Sikh organizations tend to collaborate for better results. Family is the first place to start, since the tight relationship can help inculcate the awareness of identity conservation in the young. Moreover, educational institutes, Gurdwara and other Thai Sikh organizations should help this as they are strong enough to do so. This conforms to the Structural-Functional Theory by Radcliff-Brown (Chantachon, 2010, pp. 21-23), which stated that family, religion and organizations should take part in building stability and balance in society, fostering harmony and controlling the behavior of society members.

\section{Conclusion and Suggestions}

The model of identity conservation and succession should start from examining the Thai Sikh contexts, including settlement, occupation, culture and identities. The significant aspects of identity in this research are the five K symbols, teachings and ceremonies, Gurdwara Sri Guru Singh Sabha, Sri Guru Singh Sabha Association, and Punjabi language. The problems of this conservation and succession include the changing social contexts, new culture absorption, and neglect of some Thai Sikhs. When the problems had been acknowledged, the objectives were indicated to find out the model of identity conservation and succession in order to encourage the Thai Sikhs to realize the value of their identity and collaborate in the conservation later on. After gathering information from the field study, the principles of conservation and succession were proposed. These inculcate the value awareness of significant aspects of identity, providing knowledge about significant aspects of identity and practical activities to boost conservation. This also includes organization of activities related to identity conservation, such as media, exhibitions, and demonstrations, which require collaboration between Thai Sikhs. The other factors encouraging peaceful living include paying respect to the monarchy, having stable financial status, working lawfully, accepting laws or social norms, and helping and serving the community.

Family should apply this model since it is the first place where knowledge about Sikhism, including teachings, ceremonies, practices and Punjabi language are educated. Gurdwara should use this model to provide knowledge about how to conserve and succeed the identity by organizing religious activities. Sri Guru Singh Sabha Association can produce media to foster the awareness of identity value. The Thai Sikhs themselves can do this by being aware of the significance of their identity, learning and practicing. They can start with themselves and then introduce it to other people.

\section{References}

Anon. (2013). Vision of Humanity is an initiative of the Institute for economics and Peace (IEP). Global Peace 2013. Retrieved from http://www.visionofhumanity.org/\#page/indexes/globalpeace-index/2013/THA/OVER

Chantachon, S. (2010). Cultural and Social Theory. Maha Sarakham: The Research Institute of Northeastern Arts and Culture.

Chantaronanon, P. (2008). Association between culture and identity in the culture of Thai-Chinese citizens in Buriram Province. Bangkok: Ramkamhaeng University

Davey Cunningham, J. (1853). History of the Sikhs. England: London. 
Kaur Takhar, O. (2005). Sikh Indentify an Exploration of Group Armonk Sikhs. England: Ash Gate Publishing Ltd.

Mclead, W. H. (2004). Exploring Sikhism: Aspects of Sikh Identity, Culture and Thought. England: Oxford University Press.

Mclead, W. H. (2004). Sikhs and Sikhism. UK: Oxford University Press.

Mead, G. H. (2012). Symbolic Interaction Theory. Retrieved December 5, 2012, from http://sociology.about.com/od/Sociological-Theory/a/Symbolic-Interaction-Theory.htm

Office of the National Economic and Social Development Board. (2002). Happy existence five years on from the financial crisis. Bangkok: Office of the National Economic and Social Development Board.

Sa-ee, I. (1991). The role of The Committee of Siri Guru Singh Sabha in Thai society (1932-1982). Bangkok: Thammasat University.

Sa-ee, I. (2003). The network of Indian male cloth merchants in Thai society from 1857 to 1947. Bangkok: Chulalongkorn University.

Satsanguan, N. (2008). The family institution of ethnic groups in Bangkok, Thailand: A case study of the Vietnamese (2nd Issue). Bangkok: Chulalongkorn Unversity Publishers.

Sidhu, M. S. (1993) Sikhs in Thailand. Bangkok: Institute of Asian Studies, Chulalongkorn University Press.

Singh, K. (1966). A History of the Sikh: 1839-1964 (Vol. 2). USA: Princeton University Press.

Singh, S. (2000). The Guru's word illustrated Sikh History. Princeton, Ontario: Spiritual Awakening Studies.

Siri Guru Singh Sabha Association. (2003). Guru Gobind Singh. Bangkok: Siri Guru Singh Sabha Association.

Siri Guru Singh Sabha Association. (2003). Guru Nanak, the founder of the Sikhism. Bangkok: Siri Guru Singh Sabha Association.

Siri Guru Singh Sabha Association. (2007). Religious discipline of Sikhism. Bangkok: Siri Guru Singh Sabha Association.

Siri Guru Singh Sabha Association. (2008). The gateway to Thai Sikhism: Chaloem Phra Kiat. Bangkok: Siri Guru Singh Sabha Association.

Siri Guru Singh Sabha Association. (2013). Japi Sahib. Bangkok: The Committee of Siri Guru Singh Sabha. Public Policy Development Office. (2006). The indicator of Thai happiness. Bangkok: Public Policy Development Office.

Siri Guru Singh Sabha Association. (n. d.). Sikhism. Bangkok: Burapasin Publishers.

Siri Guru Singh Sabha Association. (n. d.). What is Sikhism? Bangkok: Siri Guru Singh Sabha Association.

Wikipedia (n. d.). Sikhism by Country. Retrieved November 1, 2012, from http://en.wikipedia.org/wiki/Sikhism_by_country

\section{Copyrights}

Copyright for this article is retained by the author(s), with first publication rights granted to the journal.

This is an open-access article distributed under the terms and conditions of the Creative Commons Attribution license (http://creativecommons.org/licenses/by/3.0/). 